\title{
Annual Report of the Chairman of the Anglo-Belarusian Society for 2017
}

\author{
BY \\ BRIAN BENNETT
}

In 2017 we held an Annual General Meeting, celebrated Mother Language Day, Kupallie, Kaliady and Batliejka, took part in the Second Annual London Conference on Belarusian Studies and the 500th anniversary of the Skaryna Bible and enjoyed a choral recital given by the DL Singers in the new wooden Uniate church.

At the Annual General Meeting on 4 February 2017 we elected the society's officials, reviewed the past year and looked forward to events being prepared for 2017.

The Second Annual London Conference on Belarusian Studies was held on 25 February 2017 and organised by University College London (SEES), the Ostrogorski Centre and the Belarusian Francis Skaryna Library and Museum. Speakers came from, inter alia, Belarus, the UK, Japan, Germany and the US. It was followed by a celebratory event on 27 February 2017 given by the British Library to mark 500 years of Belarusian and East European Book Printing and the anniversary of Francis Skaryna's translation of the Bible into Belarusian, published in Prague in 1517-1519. It was attended by representatives from the Embassy of Belarus, the National Library of Belarus, the Francis Skaryna Belarusian Library and Museum in London and, of course, representatives of the British library.

Mother Language Day was celebrated on 11 March 2017 at the Belarusian Religious and Cultural Centre, Marian House. The Kupallie (midsummer) celebration was held on 1 July 2017 in the garden of 52 Penn Road and as usual included floral crowns and other floral decorations, Belarusian traditional dress, and games and songs.

The Society invited its members and friends to a recital of favourite devotional choral works in the beautiful setting of the award-winning Memorial Chapel of St Cyril of Turau at Marian House on 4 November 2017 at the kind suggestion of Father Siarhei Stasievich.

The end of year Christmas festivities were marked at Marian House in December by a Nativity Play organised by the Belarusian Sunday School and Kaliady and Batliejka. 